ACTA THERIOLOGICA

Vol. 22, 3: 67-74, 1977

\title{
Cold Acclimation in the Tundra Vole
}

\author{
Peter J. RINGENS, G. Edgar FOLK \& Joel J. BERBERICH
}

\begin{abstract}
Ringens P. J., Folk G. E. \& Berberich J. J., 1977: Cold acclimation in the tundra vole. Acta theriol., 22, 3: 67-74 [With 6 Figs.].

Two groups of tundra voles (Microtus oeconomus gilmorei S e tze r, 1952) were exposed both to control temperature $\left(17^{\circ} \mathrm{C}\right)$ and to cold $\left(4^{\circ} \mathrm{C}\right)$. Some physiological parameters involved in adaptation to the cold, such as cold diuresis, food consumption, weight loss, urinary $\mathrm{pH}, \mathrm{Na}$ and $\mathrm{K}$ were studied. Cold diuresis was found, stabilizing on a certain level after a few days, the same was found for the food consumption. The animals lost weight during the first two weeks of cold exposure, and then began to recover until they reached their original weight again. The $\mathrm{pH}$ of the urine dropped during the first days of the cold, but recovered after approximately 15 days. A circadian pattern for the $\mathrm{pH}$ was recorded, showing an increase during the 24-hour cycle, with its maximum between 5:00 AM and 9:00 AM. Interpretation of the sodium and potassium excretion in the urine is difficult as long as there are no specific data on intake " and sbalance available. However, the data can be interpreted in relationship with the $\mathrm{pH}$ data.

[Katholieke Universiteit Nijmegen, Nijmegen, The Netherlands (PJR), and Univ. Iowa, Dept. Physiol. Biophys., Iowa City, Iowa (GEF, JJB)].
\end{abstract}

\section{INTRODUCTION}

Cold acclimation has been observed in many different animals, such as lemmings (Berberich, 1975; Berberich, Folk \& Meltzer, 1971), rats (B ella my, Lam m ing \& Stevenson, 1970; Héroux, 1960; Héroux \& Hart, 1954; Sellers, Yow \& Thomas, 1951), golden hamsters (Adolph \& Richmond, 1956; Farrand, 1959; Knigge, 1957; Minor, Folk \& Dryer, 1973) and mice (Lynch, 1972). These investigations showed that adaptation to the cold means many dramatic changes within a biological system. Some of these changes were monitored by us in the tundra vole, which showed that this arctic species also acclimates to the cold.

\section{MATERIALS AND METHODS}

This study on cold acclimation was performed on the tundra vole (Microtus oeconomus gilmorei Setzer, 1952) at Point Barrow, Alaska, during May and June of 1973 and 1974. The first group consisted of nine adult animals with an average body weight at the start of the experiment of 31.4 grams; the second 
group was one of six adult voles, with an average pre-experimental body weight of 24.8 grams.

The animals used in 1973 were caught on the tundra shortly before the experiment started, whereas those used in 1974 were the laboratory-raised offspring of the former; it was not known whether this was first or later generation. The body weight of the laboratory-raised animals was approximately $20 \%$ smaller.

The animals were kept in metabolic cages and maintained on rat chow and carrots, both ad libitum. Although carrot is not a natural food for these animals, they can be maintained on it and obtain their water from it. It was observed in former experiments, during which cages were kept in an animal house with temperatures varying from $18^{\circ}$ to $20^{\circ} \mathrm{C}$, that small arctic rodents prefer wet food over drinking from a water bottle.

Both in 1973 and in 1974 they were exposed to a control environment $\left(17 \pm 1^{\circ} \mathrm{C}\right)$ for seven days. In 1973 the animals were exposed to a cold environment $\left(4 \pm 2^{\circ} \mathrm{C}\right)$ during 15 days, in 1974 for 24 days. They were maintained on a photoperiod of 22 hours of light (4:00 AM-2:00 AM) and two hours of darkness (2:00 AM 4:00 AM).

The animals were weighed daily and the carrot consumption was monitored; both measurements were done on a scale readable to 0.1 gram. We did not measure the rat chow consumption, since this was negligible.

In order to minimize transitional stress and environmental background differences, the experimental animals were maintained for three days at $17^{\circ} \mathrm{C}$ and on a diet of rat chow and carrot, before control urine collections were initiated.

Urine was collected under mineral oil. In 1974 collections were performed every four hours on control days 2 and 4, and on cold days $1,5,6,9,14$ and 24, starting with the period from 9:00 AMI to 1:00 PM. On the other days we did one four-hour collection at 1:00 PM (9:00 AM-1:00 PM) and one 20-hour collection the following morning at 9:00 AM (1:00 PM -9:00 AM). The volumes of these voidings were immediately measured by the calibration method, accurate to $0.1 \mathrm{ml}$.

Immediately after the collection the $\mathrm{pH}$ of all four-hour samples was determined with a Coleman Portable $\mathrm{pH}$ Meter, Model $37 \mathrm{~A}$, readable to $0.01 \mathrm{pH}$ units. Then samples were frozen in plastic vials, so that the sodium and potassium concentrations could be measured at the home laboratory. These measurements were performed at the University of Iowa with an IL Flame Photometer, Model 143, readable to 0.1 milliequivalents.

Of the 1973 samples 24-hour volumes were measured except that none was measured on cold day 10 , and on cold day 14 one 48 -hour volume was collected. Hence cold days 13 and 14 are expressed as averages.

\section{RESULTS}

Volume of urine produced. The volume measurements ( \pm S.E.) for both 1973 and 1974 are presented in Fig. 1. In both cases we see a cold diuresis, which reaches its final level after six days. In other words, if we use diuresis as an index, then the animal seems to be acclimated after 6 days of exposure to the cold.

$\mathrm{pH}$. Soon after cold exposure is initiated, the $\mathrm{pH}$ decreases, but is raised continually until it reaches its original level again on the 15 th 
day in the cold (Fig. 2). The $\mathrm{pH}$ increases during the day and reaches its maximum between 5:00 AM and 9:00 AM. This circadian rhythmicity is not only seen in the control period but also persists in the cold (Fig. 3).

$\mathrm{Na}^{+} / \mathrm{K}^{+}$. The pattern of the sodium and potassium concentrations in

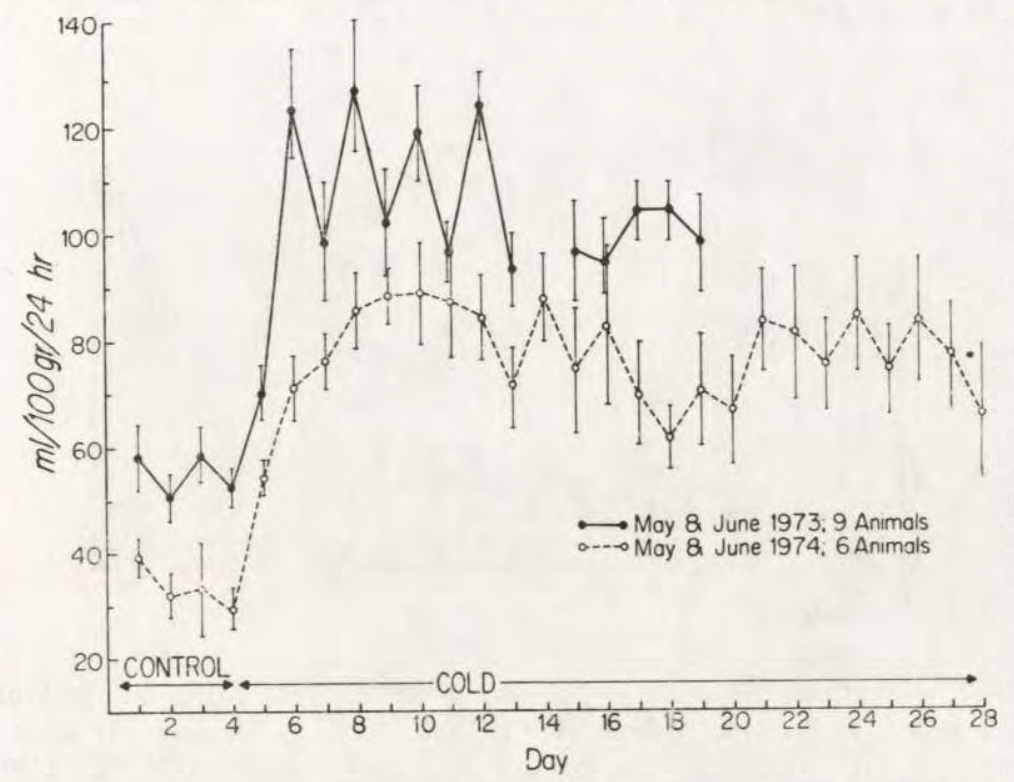

Fig. 1. Urinary output in tundra voles during control period (4 days; $17 \pm 1^{\circ} \mathrm{C}$ ) and cold exposure (15 days for the group in 1973; 24 days for the one in 1974; $4 \pm 2{ }^{\circ} \mathrm{C}$ ), expressed in milliliters $/ 100$ grams body weight/ 24 hours. (means \pm S.E.).

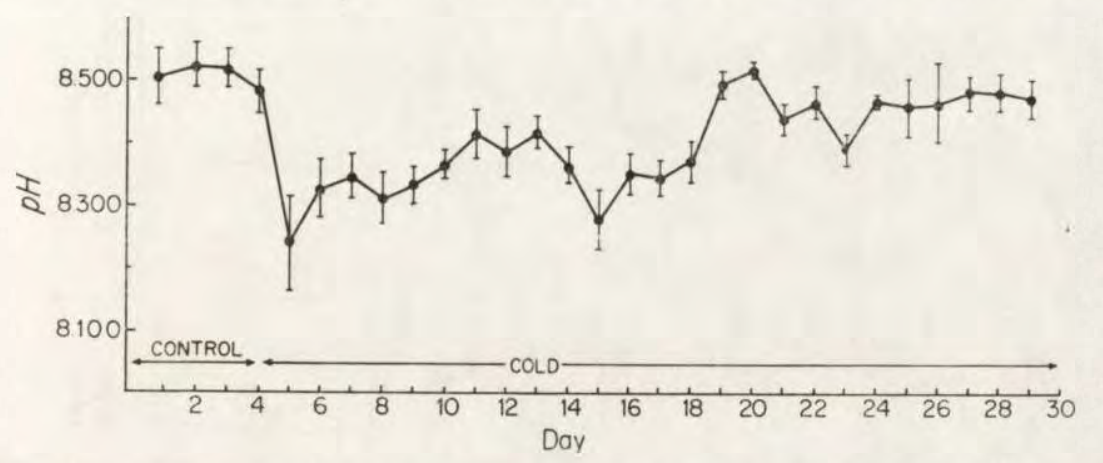

Fig. 2. Urine $\mathrm{pH}$ in tundra voles during control period (4 days; $17 \pm 1^{\circ} \mathrm{C}$ ) and cold exposure ( 24 days; $4 \pm 2{ }^{\circ} \mathrm{C}$ ). (means \pm S.E.).

the urine are presented in Fig. 4; there are no values for the cold days $17,18,19$ and 21 . Note that no significant permanent increase in the sodium concentration is seen. Potassium seems to increase and to stabilize after eight days of cold exposure. 
Body weight. This species drops its body weight during initial co.d exposure, but seems to regain and maintain original weight after approximately 15 days in the cold (Fig. 5). Hence, also in respect to the body weight the tundra vole seems to be fully acclimated after 15 dats of cold exposure.

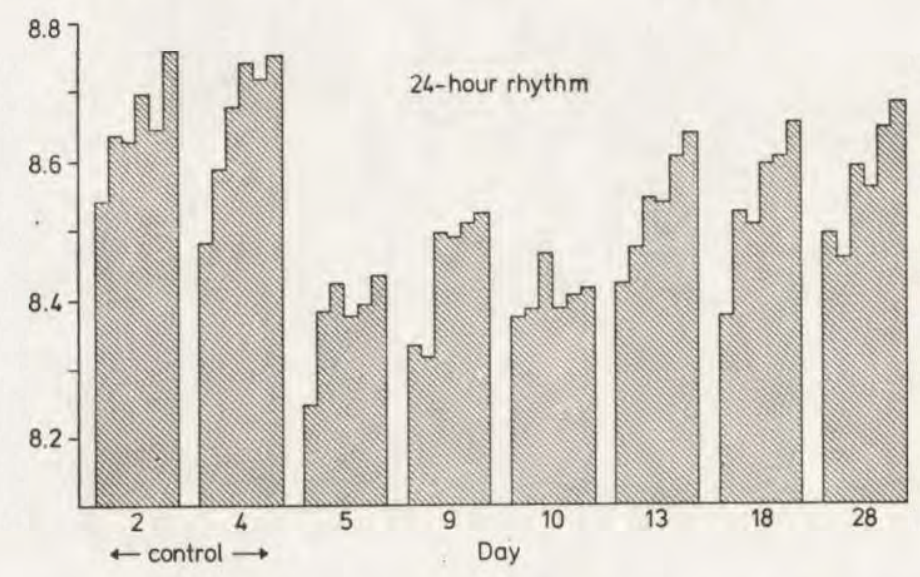

Fig. 3. 24-hour rhythm in urinary $\mathrm{pH}$ found in tundra voles on control dars $\left(17 \pm 1^{\circ} \mathrm{C}\right) 2$ and 4 and on cold days $\left(4 \pm 2^{\circ} \mathrm{C}\right) .1,5,6,9,14$, and 24 ; each gra)h represents six 4-hour measurements for the periods 9:00 AM-1:00 PM, 1:00 PM5:00 PM, 5:00 PM - 9:00 PM, 9:00 PM - 1:00 AM, 1:00 AM - 5:00 AM, 5:00 AM9:00 AM.

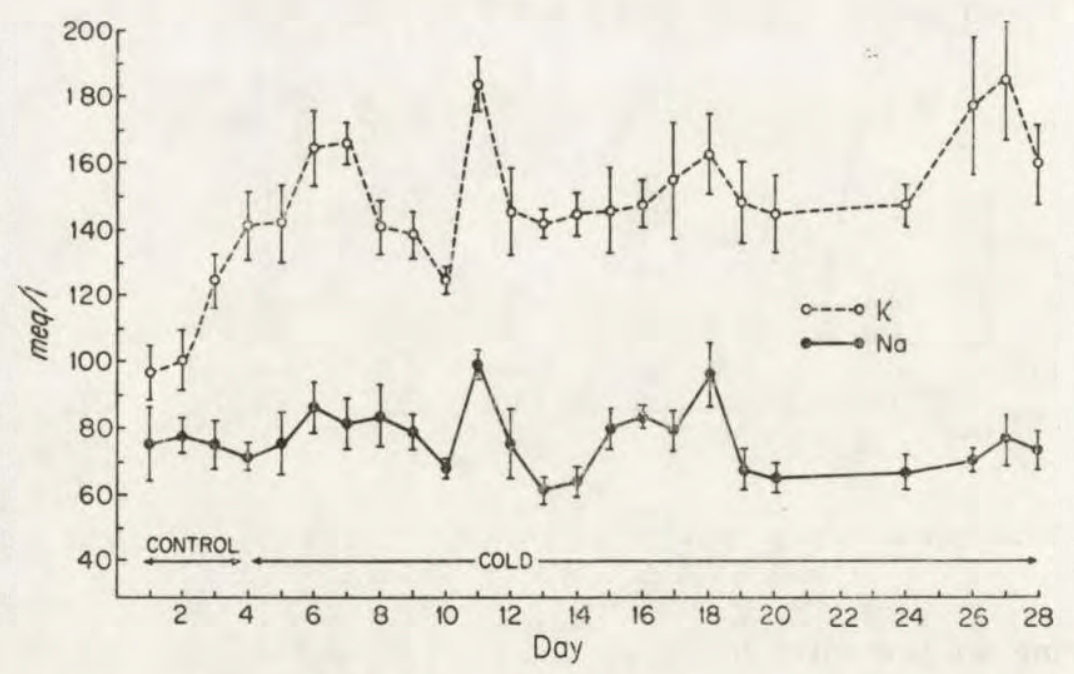

Fig. 4. Urinary sodium and potassium excretion in tundra voles during contiol period $\left(17 \pm 1^{\circ} \mathrm{C}\right)$ and cold exposure $\left(4 \pm 2^{\circ} \mathrm{C}\right)$, measured in the sample collected from 9:00 $\mathrm{AM}-1: 00 \mathrm{PM}$, expressed in milliequivalents/liter. (means \pm S.E.). 
Food consumption. The food consumption increases until it reaches a constant level after seven days of cold exposure (Fig. 6).

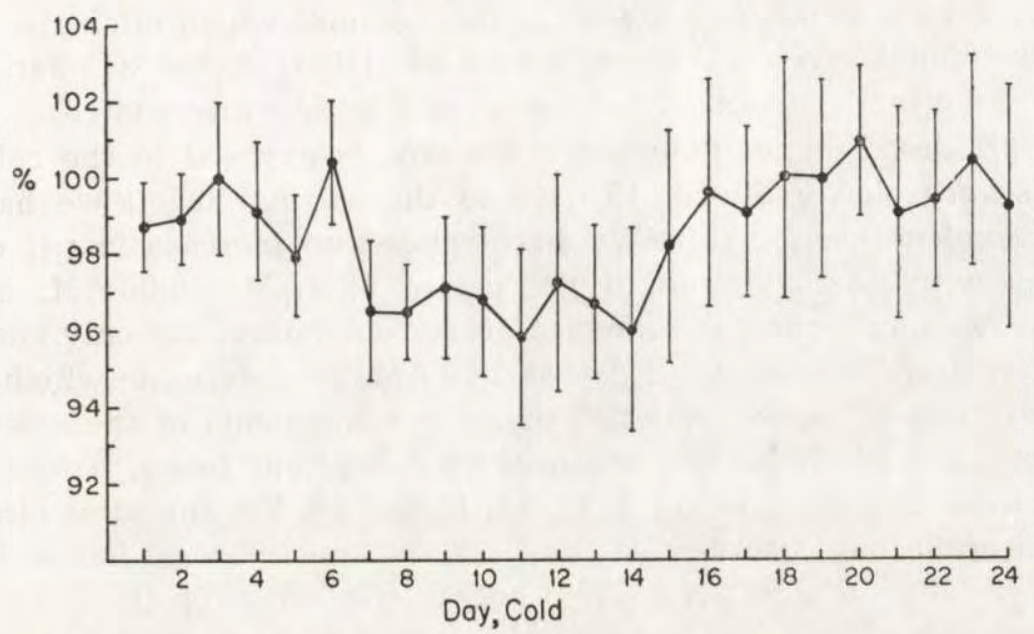

Fig. 5. Body weight of tundra voles during cold exposure $\left(4 \pm 2^{\circ} \mathrm{C}\right)$, expressed as the $\%$ of the average weight during the control period $\left(17 \pm 1^{\circ} \mathrm{C}\right)$ of 4 days. (means \pm S.E.).

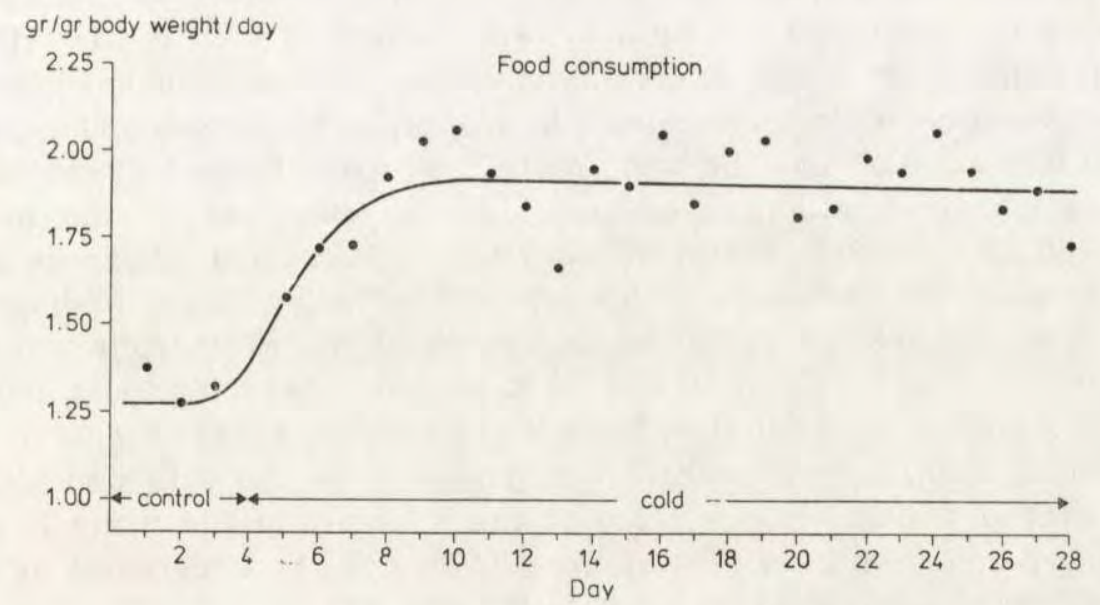

Fig. 6. Total food consumption of tundra voles during control $\left(17 \pm 1^{\circ} \mathrm{C}\right)$ and cold $\left(4 \pm 2^{\circ} \mathrm{C}\right)$ period, expressed in grams/gram body weight/24 hours.

\section{DISCUSSION}

These voles seem to show a 48-hour periodicity in voiding based upon the 1973 data, but this is not supported by the next year's study, perhaps because of the smaller sample. There is a remarkable difference in the 
volumes of the two groups, perhaps due to the physiological difference between freshly caught and laboratory-raised animals (D a w s o n, 1972; Daw son, 1975; Daw son, Stephenson \& Fredline, 1972).

However, a cold diuresis is seen in both groups, which might be a way of conserving body heat, since Reader (1952) found a relationship between thermal conductivity of tissues and their water content.

The $\mathrm{pH}$ drops immediately after the vole is exposed to the cold and returns very slowly during 15 days to the original level; we have no logical explanation for this. We first noticed an increase in $\mathrm{pH}$ during the day with its maximum in the period 5:00 AM - 9:00 AM; at this time we were collecting the samples every four hours, but only changing glassware and funnels once a day at 9:00 AM. To determine whether the peak was due to an accumulation of urine components of the glassware, we changed to clean funnels and beakers every four hours, before every new collection again, on days $9,10,13,18$ and 28 . Yet the same circadian rhythm could be observed. A similar rhythmicity was found in the golden hamster (F a r a n d, 1959) and in the lemming (Berberich, Folk \& Meltzer, 1971).

The increase in urine $\mathrm{Na}^{+}$which we find in the vole, was also described in the hamster and lemming (F a r rand, 1959; B e r berich, 1975). This increase found in the vole was not sustained, contrary to findings in the brown lemming (Berberich, 1975). Stevens \& Kido (1974) found support for the hypothesis that active sodium transport can be an important calorigenic mechanism in adaptation to the cold. The graph of the $\mathrm{K}^{+}$-excretion has the same pattern as that of the $\mathrm{Na}^{+}$-excretion (Pl a tner, 1960), although caution must be exercised in the interpretation of electrolyte excretion whenever "intake " and "balance" data are not accurately available (B a k e r, 1960). Similar to the findings of Bellamy \& Weir (1972) in six species of hystricomorphs and the findings of Berberich (1975) in the brown lemming, and unlike results found in the laboratory rat (B ellamy, Lamming \& Stevenson, 1970), the concentration of potassium in the vole was higher than that of sodium. The increase of the $\mathrm{K}^{+}$-level in the urine is also running parallel with the raise of the $\mathrm{pH}$. This can be understood by the competitive renal mechanism between $\mathrm{K}^{+}$and $\mathrm{H}^{+}$.

Initially we see a weight loss (Fig. 5) and recovery after the 15th day in the cold. This phenomenon has been noted in some other animals by Adolph \& Richmond (1956), Sellers, Yow \& Thomas (1951) and $\mathrm{S}$ mith (1962).

In the present study the major components of cold acclimation in the tundra vole are completed after 14 days of cold exposure, which is further evidence (M inor, Folk \& Dryer, 1973) that a minimum 
acclimation process of four weeks, as stated by some investigators (S ellers, 1951; Knigg e, 1957; H éroux, 1960), is not required.

Acknowledgements: We wish to express our sincere gratitude to the staff of the Naval Arctic Research Laboratory at Point Barrow, Alaska, for generous support. This study was made possible by a fellowship from the Ministerie van Onderwijs en Wetenschappen, The Netherlands and was sponsered by the Arctic Institute of North America with the approval and financial support of the Office of Naval Research under Contract Number N00014-72-A-0375-0002, Subcontract Number ONR-453, and the National Science Foundation.

\section{REFERENCES}

1. A dolph E. F. \& Richmond J., 1956: Adaptation to cold in golden hamster and ground squirrel measured chiefly by rates of body cooling. J. Appl. Physiol. 9: 53-58.

2. B a ker D. G., 1960: Influence of cold exposure on electrolyte metabolism. Fed. Proc., 19, Suppl., 5: 125-130.

3. Bellamy D., Lamming P. A. \& Stevens on A., 1970: Daily patterns. of feeding and excretion in rats confined to metabolism cages: strain and age difference. Lab. Anim. 4: 215-225.

4. Bellamy D. \& W e ir B. J., 1972: Urine composition of some hystricomorph rodents confined to metabolism cages. Comp. Biochem. Physiol. 42A: 759-771.

5. Berberich J. J., 1975: PhD thesis. University of Iowa, Iowa City. 259 pp.

6. Berberich J. J., Folk G. E. \& Meltzer M. M., 1971: Circadian rhythmicity and renal function of the hamster and lemming in a cold environment. Amer. Zool. 11: 666 .

7. Daws on N. J., 1972: Metabolic heat production of parents and offspring. Comp. Blochem. Physiol. 42A: 953-965.

8. Daws on N. J., 1975: A study of some organs and tissues in mice (Mus musculus) subjected to genetic selection for different body proportion. Comp. Biochem. Physiol. 50A: 353-358.

9. Dawson N. J., Stephenson S. K. \& Fredline D. K., 1972: Body composition of mice subjected to genetic selection for different body proportions. Comp. Biochem. Physiol. 42B: 679-691.

10. F a r r a n d R. L., 1959: Cold acclimatization in the golden hamster. State Univ. Iowa, Studies in Natural History, 20, 3:

11. Héroux O., 1960: Adjustments of the adrenal cortex and thyroid during cold acclimation. Fedn Proc. Fedn Am. Soces exp. Biol. 19: 82-85.

12. Héroux O. \& Hart J. S., 1954: Companison of four indices of adrenal activity in rats acclimated to $30^{\circ}, 15^{\circ}, 1^{\circ} \mathrm{C}$. Am. J. Physiol. 178: 445-448.

13. Héroux O. \& Hart J. S., 1954: Adrenal cortical hormone requirement of warm and cold acclimated rats after adrenalectomy. Am. J. Physiol. 178: $449-452$.

14. Héroux O. \& Hart J. S., 1954: Cold acclimation and adrenal cortical activity as measured by eosinophil levels. Am. J. Physiol. 178: 453-456.

15. Knigge K. M., 1957: Influence of cold exposure upon the endocrine glands of the hamster, with an apparent dichotomy between morphology and functional response of the thyroid. Anat. Rec. 127: 75-95.

16. Lynch G. R., 1972: Effects of temperature and photoperiod on thermoregulation in the white-footed mouse. $\mathrm{PhD}$ thesis, University of Iowa, Iowa City. $101 \mathrm{pp}$. 
17. Minor J. G., Folk G. E. \& Dryer R. L., 1973: Changes in triglyceride composition of white and brown adipose tissues during developing cold acclimation of the golden hamster Mesocricetus auratus. Comp. Biochem. Physiol. 46B: $375-385$.

18. Platner W. S., 1960: Electrolytes in acclimation to cold. Fed. Proc., 19, Suppl., 5: 130-131.

19. R e a der S. R., 1952: Effective thermal conductivity of normal and rheumatic tissues in response to cooling. Clin. Sc. 11: 1-12.

20. Sellers E. A., 1951: Acclimatization. Cold Injury, Transactions of the First Congress. pp. 181-235, Josiah Macy, Jr. Foundation, New York.

21. Sellers E. A., Yow S. S. \& Thomas N., 1951: Acclimatization and survival of rats in cold: effects of clipping, of adrenalectomy and of thyroidectomy. Am. J. Physiol. 165: 481-485.

22. Smith R. E., 1962: Cold acclimation - an altered steady state. J.A.M.A. 179: 948-954.

23. Stevens E. D. \& Kido M., 1974: Active sodium transport: a source of metabolic heat during cold adaptation in mammals. Comp. Biochem. Physiol. 47A: $395-397$.

Accepted, March 17, 1976.

Peter J. RINGENS, G. Edgar FOLK, Joel J. BERBERICH

\section{AKLIMATYZACJA DO CHEODU U NORNIKA POENOCNEGO}

\section{Streszczenie}

Badano kilka parametrów fizjologicznych, takich jak: pabieranie pokarmu, utratę ciężaru ciała, wydalenie moczu, jego $\mathrm{pH}$ oraz poziom $\mathrm{Na} \mathrm{i} \mathrm{K}$ u dwu grup nornika północnego (Microtus oeconomus gilmorei Setzer, 1952) trzymanych w temperaturze $17^{\circ} \mathrm{C}$ (kontrola) i $4^{\circ} \mathrm{C}$. Pod wplywem chłodu wydzielanie moczu wzrasta nadmiernie, lecz po kilku dniach ustala się na pewnym poziomie (Ryc. 1), tak samo jak i konsumpcja pokarmu (Ryc. 6). Zwierzęta traciły na wadze przez początkowe dwa tygodnie ekspozycji w $4^{\circ} \mathrm{C}$, a następnie stopniowo zwiększały swój ciężar, aż do osiągnięcia początkowej wartości (Ryc. 5). W początkowym okresie działania chłodu pH moczu zniża się, po czym powraca do normy po około 15 dniach (Ryc. 2). Obserwowano też dobowy rytm pH i określono, że jego maksimum przypada na godziny od 17 do 21 (Ryc. 3). Choć objaśnienie zmian w wydzielaniu sodu i potasu (Ryc. 4) z moczem nie jest latwe, gdyź brak jest danych o pobraniu i bilansie tych pierwiastków, to należy to wiązać ze zmianami $\mathrm{pH}$ moczu. 